\title{
Biomechanical Comparison of The Effects of The Storage Temperature on Tibiotarsus in Japanese Quail
}

\author{
๑ Bayram Suzer \\ Department of Anatomy, Faculty of Veterinary Medicine, Bursa Uludag University, Nilufer/Bursa, 16059, Turkey
}

Received 22-11-2021 Accepted 18-12-2021

\begin{abstract}
The study aimed to compare the effects of different cryopreservation temperatures on mechanical properties and determine the optimal cryopreservation temperature for bones in Japanese quail. Bone biomechanical tests are getting more attention but, fresh bones are not always available for testing and have a limited lifespan. Cryopreservation of biological specimens is often needed during tissue preparation and mechanical testing. In the study, the tibiotarsi were collected from 8 weeks of age quail, and bones were divided into four groups of fresh bones; frozen at $0{ }^{\circ} \mathrm{C}$, frozen at $-20^{\circ} \mathrm{C}$, and frozen at $-80^{\circ} \mathrm{C}$. Frozen bones were kept in the freezer for three weeks. After three weeks, bones were subjected to a three-point bending test for biomechanical evaluation. There was no significant difference between the mechanical strength properties of fresh tibiotarsi and the tibiotarsi stored in three different storage conditions of $0^{\circ} \mathrm{C},-20^{\circ} \mathrm{C}$, or $-80^{\circ} \mathrm{C}$. It was observed that cryopreservation of tibiotarsi at $0,-20$, and $-80^{\circ} \mathrm{C}$ for up to three weeks did not negatively affect bone biomechanical properties in quail.
\end{abstract}

Keywords: Biomechanics, cryopreservation, freezing, storage temperature.

\section{Introduction}

Over the past decades, bone-breaking strength received more attention. Bone measurements such as bone fracture strength, bone ash, bone ash concentration, bone mineral content, and bone density have been used as crucial indicators of bone status in poultry ${ }^{1-6}$. It is often impractical to test freshly harvested bone $e^{7}$. On the other hand, fresh bones are not always available, have a limited lifespan (approx. three weeks), and have difficulties in shipping or handling. Cryopreservation of biological specimens is often unavoidable during tissue preparation and mechanical testing. In particular, it becomes difficult to immediately process bone samples to measure bone strength and other parameters with large numbers of animals. Therefore, if large amounts of bone cannot be processed simultaneously, an effective procedure is required to preserve and stabilize bone mineralization in the bone ${ }^{9}$. Postmortem storage has been used for biomechanical measurement of living tis- sues, as it is impossible to perform tests in vivo or immediately after sacrifice ${ }^{10}$. Therefore, cryopreservation of tissue samples before mechanical testing has become an accepted technique ${ }^{11}$. However, it is still criticized whether preservation methods affect bone properties or bone strength.

Researchers have conducted several studies to understand the effects of freezing and thawing on bone mechanical properties on various species such as chickens ${ }^{9}, \operatorname{dogs}^{11}$, mice ${ }^{12}$, rats $^{13}$, pigs $^{14}$, and deer ${ }^{15}$. In recent years, the use of Japanese quail (Coturnix coturnix japonica) in biomedical research has increased ${ }^{16}$, and its use in biological, genetic, aging, and disease research has become widespread ${ }^{7}$. However, it is not known about the effects of freezing at different temperatures on bone properties in quail. Therefore, this experiment aimed to compare the effects of different storage temperatures on some mechanical properties and determine the optimal cryopreservation temperature for future bone biomechanical tests in Japanese quail.

* Corresponding author: Bayram Suzer, Department of Anatomy, Faculty of Veterinary Medicine, Bursa Uludag University, Nilufer/ Bursa, 16059, Turkey, +902242940867, suzer@uludag.edu.tr 


\section{Material and Methods}

Animals and Bone Collection

The tibiotarsi were collected from eight weeks of age quail raised for commercial production (slaughtering material) in Animal Health and Animal Production Research and Application Center in Bursa Uludag University Faculty of Veterinary Medicine. The quail were divided into four groups, and a total of twenty-four quail were used, with six quail in each group. Experimental groups were: fresh bones; frozen at $0{ }^{\circ} \mathrm{C}$ (Nuve ES120, NUVE, Ankara, Turkey); frozen at $-20^{\circ} \mathrm{C}$ (Bosch KSU3921NE/01, Robert Bosch $\mathrm{GmbH}$, Gerlingen, Germany), and frozen at $-80{ }^{\circ} \mathrm{C}$ (Forma 88000 Series, Thermo Scientific, Massachusetts, United States). After sacrifice, the bones were cleaned surrounding soft tissues. Before freezing, the bones were wrapped in physiological saline $(0.9 \% \mathrm{NaCl})$ solution-soaked gauze and bagged to prevent drying and tagged ${ }^{17}$. Then, the bones were frozen at different temperatures $\left(0,-20\right.$, and $\left.-80{ }^{\circ} \mathrm{C}\right)$ until mechanical tests and cortical area analysis were conducted.

\section{Freezing and thawing procedure}

1. The fresh group consisted of fresh bones, and mechanical tests were performed at room temperature within 45 minutes after bone collection.

2. The bones in the $0^{\circ} \mathrm{C}$ group were stored in sealed plastic bags at $0 \mathrm{oC}$ for 3 weeks, then thawed at $37^{\circ} \mathrm{C}$ in an oven (Nuve ES120, NUVE, Ankara, Turkey) for $1 \mathrm{~h}$ and to be followed by the mechanical test at room temperature.

3. The bones in the $20^{\circ} \mathrm{C}$ group were stored in sealed plastic bags at $-20^{\circ} \mathrm{C}$ for 3 weeks, then they were defrosted at $37^{\circ} \mathrm{C}$ in an oven (Nuve ES120, NUVE, Ankara, Turkey) for $1 \mathrm{~h}$, and the mechanical test was performed at room temperature after thawing.

4. The bones in the $80^{\circ} \mathrm{C}$ group were stored in sealed plastic bags at $-80^{\circ} \mathrm{C}$ for 3 weeks, then they were defrosted at $37{ }^{\circ} \mathrm{C}$ in an oven (Nuve ES120, NUVE, Ankara, Turkey) for $1 \mathrm{~h}$, and the mechanical test was performed at room temperature afterward 13 .

\section{Mechanical Testing}

A three-point bending test was performed on each tibiotarsus of quail after the freeze-thaw procedure. A custom-made testing machine, designed by Dr. Kenan Tufekci, according to Tufekci et al. ${ }^{18}$, was used to measure force and corresponding displacement for low-strength materials. The tests were performed at a constant loading head speed of $10 \mathrm{~mm} / \mathrm{min}^{19}$. The average tibiotarsus length was $49.44 \pm 1.56 \mathrm{~mm}$; therefore, the span between supports was adjusted to $40 \%$ of the total bone length, $20 \mathrm{~mm}$, and the load was applied to the midpoint of the bone length at the middle of the span. The loading was applied with a constant speed of the load head until the bones broke. Ultimate load (Fmax)was read as the highest load from the load-displacement curve. Subsequently, mid-shaft sections of tibiotarsus were obtained from the fracture site with a wire saw, and sections were photographed under a stereomicroscope (Motic, Model: SMZ-168, Hong Kong). Solidworks R17 3D CAD software (Dassault Systèmes, Waltham, MA; USA) was used for determining the cortical area (Acort) and the minimum principal moment of inertia (Imin). Young's modulus or modulus of elasticity (E) was calculated by using the following equation:

$\mathrm{E}=(\mathrm{FL} 3) /(48 \delta \operatorname{Imin})$

Imin is the minimum principal moment of inertia, $\mathrm{F}$ is the ultimate load, $\mathrm{L}$ is the length between support, $\delta$ is the displacement under the corresponding force.

\section{Statistical analysis}

As the correlation coefficient for the breaking strength of right and left tibias of broiler chickens is at least 0.90 for fresh bones 20 , the paired bone technique was used, and left and right tibiotarsi were combined to conduct the statistical analysis. Statistical analyses were performed with IBM SPSS (SPSS, Version 23.0; Chicago, IL). Data were tested for normality of distribution and homogeneity of variances, and one-way analysis of variance (one-way ANOVA) was used for statistical evaluation.

\section{Results}

Results of the mechanical three-point bending test and bone properties are presented in Table 1. As a result of three-week freezing, there was no significant difference between the mechanical strength characteristics (ultimate load, minimum moment of inertia, Young's modulus, cortical area) of fresh tibiotarsi and the tibiotarsi stored in three different storage conditions of $0{ }^{\circ} \mathrm{C}, 20^{\circ} \mathrm{C}$ or $80 \mathrm{oC}$. Likewise, no significant differences were observed between different storage conditions $(\mathrm{PFmax}=0.657$; $\mathrm{PImin}=0.393$; $\mathrm{PE}=0.731$; PAcort $=0.317$ ).

Table 1. Mechanical properties of tibiotarsus measured after different storage methods

\begin{tabular}{c|c|c|c|c}
\hline & $\mathbf{F}_{\max }(\mathbf{N})$ & $\mathbf{I}_{\min }\left(\mathbf{m m}^{\mathbf{4}}\right)$ & $\boldsymbol{E} \mathbf{( G P a )}$ & $\mathbf{A}_{\text {cort }}\left(\mathbf{m m}^{2}\right)$ \\
\hline Fresh & $38.268 \pm 2.006$ & $1.656 \pm 0.131$ & $11.569 \pm 0.967$ & $2.865 \pm 0.059$ \\
\hline $\mathbf{0}{ }^{\circ} \mathbf{C}$ & $37.332 \pm 1.557$ & $1.646 \pm 0.062$ & $11.741 \pm 0.577$ & $3.050 \pm 0.103$ \\
\hline $\mathbf{2 0}^{\circ} \mathbf{C}$ & $40.509 \pm 2.012$ & $1.811 \pm 0.074$ & $12.124 \pm 1.179$ & $3.017 \pm 0.077$ \\
\hline $\mathbf{8 0}^{\circ} \mathbf{C}$ & $39.248 \pm 1.741$ & $1.901 \pm 0.175$ & $12.838 \pm 0.509$ & $2.924 \pm 0.048$ \\
\hline P value & 0.657 & 0.393 & 0.731 & 0.317 \\
\hline
\end{tabular}

${ }^{\star}$ Data were presented as Mean \pm SEM (Standart Error of Mean)

${ }^{*}$ Significance was assessed at the level of $\mathrm{P}<0.05$.

Fmax: Ultimate load, Imin: Minimum moment of inertia, E: Young's modulus, Acort: Cortical area. 


\section{Discussion}

Especially in large-scale biomechanical studies, it is not always possible to work with fresh bones immediately after animal sacrifice. Therefore, researchers used several storage methods at different temperatures at various times. Unlike most studies, an avian species, quail, was used instead of a mammalian species in the present study. Park et al. ${ }^{9}$ and Lott et al. ${ }^{21}$ also investigated the effects of cryopreservation on the mechanical properties of chicken bones. In the present study, quail was selected because its importance has increased in biomedical studies in recent years16. The experiment was designed to examine the effects of freezing at $0^{\circ} \mathrm{C},-20^{\circ} \mathrm{C}$, and $-80 \mathrm{oC}$ on some biomechanical properties of the tibiotarsus in quail. This experiment is also the first study comparing the bone biomechanical properties of quail tibiotarsus at different cryopreservation temperatures.

Researchers used different temperatures between $-18{ }^{\circ} \mathrm{C}$ and $-70{ }^{\circ} \mathrm{C}$ for various periods before testing specific biomechanical properties of human and animal bones, such as rigidity and elasticity ${ }^{22}$ bending, torsion, toughness, and stiffness $^{23}$ and ultimate load ${ }^{24,25}$. Based on the previous literature, changes in bone biomechanical properties were assessed with various freezing or cooling storage methods by using compression and bending tests ${ }^{26}$. Literature suggested that mechanical characteristics may be affected by different storage methods, but significant alterations can only be observed in the case of long-term storage ${ }^{27-31}$.

In the present study, the effect of various storage temperatures was compared with fresh tibiotarsi and tibiotarsi frozen for three weeks in quail. The results show that there were no significant changes in tibiotarsal mechanical properties in different storage freezing temperatures. Similarly, Nazarian et al. ${ }^{26}$ reported that freezing of murine femurs and vertebrae over two weeks did not change the elastic mechanical properties of the femurs. Freezing of human femoral cortical bone specimens ${ }^{29}$ and feline humerus and femur $^{32}$ did not affect the bone mechanical properties in humans and cats, respectively. Borchers et al. ${ }^{33}$ also suggested that freezing to either $-20{ }^{\circ} \mathrm{C}$ or $-70{ }^{\circ} \mathrm{C}$ did not affect the mechanical properties of trabecular bone in cows. Furthermore, freezing did not affect the mechanical properties of the trabecular bone $e^{27,33-35}$.

Many researchers reported that freezing the bones for less than five years had no significant adverse effect on bone morphology or function ${ }^{22-25,33,36}$. In contrast to our findings and the studies above, Lott et al..$^{21}$ observed only minor alterations in bone strength between fresh and frozen bones at $-18{ }^{\circ} \mathrm{C}$ for 48 hours. Lee and Jasiuk ${ }^{37}$ also observed that storing the femur at $-20^{\circ} \mathrm{C}$ for five years significantly reduced Young's modulus and ultimate strength. These re- searchers brought a perspective to this effect and suggested a possible reason for differences in mechanical properties of the bone is the formation and enlargement of ice-crystals ${ }^{37}$. When the bones are frozen at $-20^{\circ} \mathrm{C}$, the bones slowly lose moisture due to evaporation ${ }^{38}$, which increases the size of the ice crystals and causes structural damage to the bone tissue ${ }^{39}$. Lee and Jasiuk ${ }^{37}$ also suggested that cellular enzymes could be another reason for bone degradation. The enzymes that degrade the organic matrix are still effective at $-20^{\circ} \mathrm{C}$. To avoid cellular destruction, temperatures of -70 degrees and below should be preferred for long-term storage conditions ${ }^{37}$.

In conclusion, it was observed that cryopreservation of tibiotarsi at $0,-20$, and $-80{ }^{\circ} \mathrm{C}$ for up to three weeks did not negatively affect bone biomechanical properties in quail. Therefore, researchers can use $0,-20$, and $-80{ }^{\circ} \mathrm{C}$ temperatures as a convenient preservation method in quail species. In future studies, by planning a study longer than one year, comparing the bone mechanical properties is recommended to examine the long-term effects of cryopreservation temperature.

\section{Conflict of interest}

The author declares no conflict of interest.

\section{References}

1. Akpe MP, Waibel PE, Larntz K, Metz AL, Noll SL, Walser MM. Phosphorus availability bioassay using bone ash and bone densitometry as response criteria. Poult Sci. 1987;66(4):713-720.

2. Watkins KL, Southern LL. Effect of dietary sodium zeolite A and graded levels of calcium and phosphorus on growth, plasma, and tibia characteristics of chicks. Poult Sci. 1992;71(6):1048-1058.

3. Garlich J, Morris C, Brake J. External bone volume, ash, and fat-free dry weight of femurs of laying hens fed diets deficient or adequate in phosphorus. Poult Sci. 1982;61(5):1003-1006.

4. Cheng TK, Coon CN. Sensitivity of various bone parameters of laying hens to different daily calcium intakes. Poult Sci. 1990;69(12):2209-2213.

5. Merkley JW. A comparison of bone strengths from broilers reared under various conditions in coops and floor pens. Poult Sci. 1981;60(1):98-106.

6. Ruff CR, Hughes BL. Bone strength of height-restricted broilers as affected by levels of calcium, phosphorus, and manganese. Poult Sci. 1985;64(9):1628-1636.

7. Huss D, Poynter G, Lansford R. Quails as lab animal. 2008;37(11):513-519.

8. Ravicz ME, Merchant SN, Rosowski JJ. Effect of freezing and thawing on stapes-cochlear input impedance 
in human temporal bones. Hear Res. 2000;150(12):215-224.

9. Park SY, Birkhold SG, Kubena LF, Nisbet DJ, Ricke SC. Effect of storage condition on bone breaking strength and bone ash in laying hens at different stages in production cycles. Poult Sci. 2003;82(11):1688-1691.

10. Ho NB, Meng CS. The effect of postmortem freezing storage on the tensile properties of tendon. Proc IEEE Annu Northeast Bioeng Conf NEBEC. Published online 2002:53-54.

11. Gottsauner-Wolf F, Grabowski JJ, Chao EYS, An K -N. Effects of freeze/thaw conditioning on the tensile properties and failure mode of bone-muscle-bone units: A biomechanical and histological study in dogs. J Orthop Res. 1995;13(1):90-95.

12. McElderry J-DP, Kole MR, Morris MD. Repeated freeze-thawing of bone tissue affects Raman bone quality measurements. J Biomed Opt. 2011;16(7):071407.

13. Suto K, Urabe K, Naruse K, et al. Repeated freezethaw cycles reduce the survival rate of osteocytes in bone-tendon constructs without affecting the mechanical properties of tendons. Cell Tissue Bank. 2012;13(1):71-80.

14. Szebényi G, Görög P, Török A, Kiss RM. Effect of different conservation methods on some mechanical properties of swine bone. WIT Trans Biomed Heal. 2013;17:225-233.

15. Pokines JT, King RE, Graham DD, et al. The effects of experimental freeze-thaw cycles to bone as a component of subaerial weathering. J Archaeol Sci Reports. 2016;6:594-602.

16. Minvielle F. The future of Japanese quail for research and production. Worlds Poult Sci J. 2004;60(4):500507.

17. Easton KL, Kawcak CE. Evaluation of increased subchondral bone density in areas of contact in the metacarpophalangeal joint during loading in horses. Am J Vet Res. 2007;68(8):816-821.

18. Tufekci K, Kayacan R, Kurbanoglu C. Effects of gamma radiation sterilization and strain rate on compressive behavior of equine cortical bone. J Mech Behav Biomed Mater. 2014;34:231-242.

19. Lopez MJ, Markel MD. Bending tests of bone. In: An YH, Draughn RA, eds. Mechanical testing of bone and the bone-implant interface. Boca Raton, CRC press; 2000:209-210.

20. Stien C. A two-sample test for a linear hypothesis whose power is independent of the variance. Ann Math Stat. 1945;16:243-258.

21. Lott BD, Reece FN, Droit JH. Effect of preconditioning on bone breaking strength. Poult Sci. 1980;59:724-725.
22. Gleizes V, Viguier E, Féron JM, Canivet S, Lavaste F. Effects of freezing on the biomechanics of the intervertebral disc. Surg Radiol Anat. 1998;20:403-407.

23. Van Haaren EH, van der Zwaard BC, van der Veen AJ, Heyligers IC, Wuisman PI, Smit TH. Effect of longterm preservation on the mechanical properties of cortical bone in goats. Acta Orthop. 2008;79:708-716.

24. Kaye B, Randall C, Walsh D, Hansma P. The effects of freezing on the mechanical properties of bone. Open Bone J. 2012;4:14-19.

25. Torimitsu S, Nishida Y, Takano T, Koizumi Y, Hayakawa M, Yajima D, Inokuchi G, Makino Y, Motomura A, Chiba F, Iwase H. Effects of freezing and thawing process on biomechanical properties of the human skull. Legal Med. 2014;16:102-105.

26. Nazarian A, Hermannsson BJ, Muller J, Zurakowski $\mathrm{D}$, Snyder BD. Effects of tissue preservation on murine bone mechanical properties. J Biomech. 2009;42:8286.

27. Linde F, Sorensen HCF. The effect of different storage methods on the mechanical properties of trabecular bone. J Biomech. 1993;26:1249-1252.

28. Beaupied H, Dupuis A, Arlettaz A, Brunet-Imbault B, Bonnet N, Jaffre C, Benhamou, CL, Courteix D. The mode of bone conservation does not affect the architecture and the tensile properties of rat femur. Biomed Mater Eng. 2006;16:253-259.

29. Sedlin ED. A rheologic model for cortical bone: A study of the physical properties of human femoral samples. Acta Orthop Scan. 1965;S83:1-77.

30. Unger S, Blauth M, Schmoelz W. Effects of three different preservation methods on the mechanical properties of human and bovine cortical bone. Bone. 2010;47:1048-1053.

31. Öhman C, Dall'Ara E, Beleani M, van Sint Jan S, Viceconti $\mathrm{M}$. The effects of embalming using a $4 \%$ formalin solution on the compressive mechanical properties of human cortical bone. Clin Biomech. 2008;23:2941298.

32. Goh JC, Ang EJ, Bose K. Effect of preservation medium on the mechanical properties of cat bones. Acta Orthop Scand. 1989;60:465-467.

33. Borchers RE, Gibson LJ, Burchardt H, Hayes WC. Effects of selected thermal variables on the mechanical properties of trabecular bone. Biomaterials. 1995; 16:545-551.

34. Panjabi MM, Krag M, Summers D, Videman T. Biomechanical time- tolerance of fresh cadaveric human spine specimens. J Orthop Res. 1985;3:292-300.

35. Kang Q, An YH, Friedman RJ. Effects of multiple freezing-thawing cycles on ultimate indentation load 
and stiffness of bovine cancellous bone. Am J Vet Res. 1997;58:1171-1173.

36. Jung HJ, Vangipuram G, Fisher MB, Yang G, Hsu S, Bianchi J, Ronholdt C, Woo SLY. The effects of multiple freeze-thaw cycles on the biomechanical properties of the human bone-patellar tendon-bone allograft. J Orthop Res. 2011;29:1193-1198.

37. Lee W, Jasiuk I. Effects of freeze-thaw and micro-computed tomography irradiation on structure-property relations of porcine trabecular bone. J Biomech. 2014;47:1495-1498.

38. Stromberg L, Dalen N. The influence of freezing on the maximum torque capacity of long bones. An experimental study on dogs. Acta Orthop Scand. 1976;47:254-256.

39. Brown KL, Cruess RL. Bone and cartilage transplantation in orthopaedic surgery. A review. J Bone Joint Surg. 1982;64:270-279. 